\title{
FUNCTIONAL STATE OF NEUTROPHIC GRANULOCYTES' GENOME OF THE PERIPHERAL BLOOD IN PATIENTS WITH CHRONIC HEPATITIS C WITH CONCOMITANT DIABETES MELLITUS TYPE II
}

DOI: 10.36740/WLek202008116

\author{
Oleksandra Ya. Pryshliak, Larysa Ye. Kovalchuk, Oleksandra V. Marynchak, Oleksandr P. Boichuk, Ihor H. Hryzhak, \\ Oksana Ye. Kondryn, Valentyna F. Piuryk \\ IVANO-FRANKIVSK NATIONAL MEDICAL UNIVERSITY, IVANO-FRANKIVSK, UKRAINE
}

\begin{abstract}
The aim: To determine changes of FSG of neutrophilic granulocytes of peripheral blood (NGPB) of patients with CHC with concomitant DM-2.

Materials and methods: We've examined 180 patients with CHC: 160 with concomitant diabetes mellitus and 20 ones without it. The NGPB genome was studied using cytogenetic method. There were analyzed 100 interphase NGPB nuclei in the preparation, structural characteristics were evaluated according to indices: chromatization (IC), nucleolar (IN), pathologically altered nuclei (PAN), micronuclei (MNI).

Results: Violations of FSG OF NGPBwere found according to all indices in patients with CHC, they were more pronounced in patients with concomitant DM-2.

Conclusions: FSG NGPB is more disordered in CHC with concomitant DM-2. The reduction of IC in CHC with concomitant DM-2 is more pronounced in men. Reduction of IN in patients with $\mathrm{CHC}$ with and without DM-2 is a marker of violations of the second stage of realization of hereditary information. The tendency to change the components of the cytogenetic status of all examined patients due to the frequency of MNI was determined.
\end{abstract}

KEY WORDS: Epigenetic disorders, functional state of genome, chronic hepatitis C, type 2 diabetes mellitus

Wiad Lek. 2020;73(8):1671-1676

\section{INTRODUCTION}

Chronic hepatitis $\mathrm{C}(\mathrm{CHC})$ remains one of the most topical medical and social problems of modern medicine nowadays [1]. According to WHO data, the number of chronically infected persons with hepatitis $\mathrm{C}$ virus (HCV) in the world is 71 million people, causing a pandemia, that will be observed for several decades, despite the advances in current schemes of therapy [2]. The peculiarity of the problem is that HCV-infection goes without clear clinical symptoms for a long time, which causes its late diagnosis (in $75-85 \%$ already in the stage of the formed chronic form), with a further rapid progression to the development of liver cirrhosis (LC) and hepatococellular carcinoma (HCC) [3].

Since CHC is a significant medical-social problem and occurs frequently, it is natural to understand that this infectious process can be observed in combination with various comorbid somatic diseases $[2,3]$.

Diabetes mellitus (DM) - is one of the most common endocrine diseases. In developed countries, its frequency in the population is $4-5 \%$ [4]. Currently, diabetes mellitus is given a prominent place just after cardiovascular and oncological diseases according to the medico-social importance [5]. Nowadays, HCV-infection could be called a predictor of the development of carbohydrate metabolism and, accordingly - of the development of type 2 diabetes mellitus $[6,7]$, and the presence of type DM-2 in patients with $\mathrm{CHC}$ increases the progression of this disease with the development of HCC (in 13\% vs $5.9 \%$ in the comparison group) due to stimulation of HCC cell proliferation in vitro $[8,9]$. That is, an important problem of modern infectology is the study of peculiarities of the course of infectious pathology against the background of various somatic conditions [10]. In the scientific literature, there are the reports on the mutual-aggravating effect of $\mathrm{CHC}$ and type DM-2, which is manifested by an increase of clinical symptoms and the emergence of new clinical manifestations, in the more severe course of the disease and in the rapid occurrence of complications and adverse effects, reduction of the effectiveness of antiviral treatment $[11,12]$.

In any disease the pathological changes are manifested at the cellular level and are accompanied by the violation of certain processes of regulation of metabolism, disorders of hereditary information of the genome, which leads to changes in its functional state $[13,14,15]$. Epigenetic mechanisms (gene expression, regulation of chromatin structure, cell differentiation, DNA replication, inactivation of the X-chromosome) are involved into the control of many important biological processes in the body $[16,17]$. In connection with the above-mentioned, the functional state of the genome (FSG) of neutrophilic granulocytes' peripheral blood (NGPB) in many complex and multifactorial diseases is being studied $[18,19,20,21,22]$. During the study of cytogenetic parameters in patients 
with chronic hepatitis $(\mathrm{CH})$ according to the indeces of karyogram of interphase nuclei of hepatocytes, scientists have determined the dependence of disorders of chromatin compactization, the value of the nuclear index (IN) of the severity of metabolic intoxication, which is confirmed by the inverse correlation between the above-noted indicators and the blood content of lipid peroxidation products [23, $24,25]$. The association of FSG with indices of cellular link of immunity in patients with chronic hepatitis B and alcoholic liver disease has been established [16, 23, 24]. In $\mathrm{DM}$ of HCV- and HBV-etiology, transcription-translation apparatus disorders deepen [26, 27]. Hepatitis $C$ virus is known to have high genetic variability, is a potent inducer of oncogenesis without integration of the virus into the patient's genome [26], that's why more pronounced changes in the hepatocyte genome under the influence of HCV-infection compared to HBV-infection may be one of the causes.

The literature does not sufficiently describe data concerning the study of changes in cytogenetic indices in patients with $\mathrm{CHC}$, and especially with concomitant somatic diseases. Therefore, we can say with certainty that the study of the state of chromatin serves as an informative indicator of the formation of all body cells (including hepatocytes) and their functions throughout the life of tissues. We believe that the study of genetic markers greatly expands our understanding of the evolution of the human body and allows us to trace the genetic aspects in the liver pathology, reveals new horizons in the cognition of intimate mechanisms of organism functioning and pathological processes in many diseases.

\section{THE AIM}

To detect alterations in the functional state of the genome of neutrophilic granulocytes of peripheral blood of patients with chronic hepatitis $\mathrm{C}$ with concomitant type 2 diabetes mellitus.

\section{MATERIALS AND METHODS}

There were studied 160 patients with $\mathrm{CHC}$ with concomitant DM type 2, who were in the main group of the study, aged from 30 to 65 years ( 80 women and 80 men) with the duration of the disease from 5 to 15 years, who were treated at the Regional Clinical Infectious Hospital of Ivano-Frankivsk (Ukraine) during 2009-2017. The diagnosis of $\mathrm{CHC}$ was determined on the basis of clinical, ultrasound, biochemical and immunological studies.

In addition to general clinical research methods, all patients were determined by the functional state of genome of the NGPB using the cytogenetic method of interphase nuclei study.

For this purpose, cytological preparations were made from leukocytes of peripheral blood, which after drying were stained according to Feulgen in the modification of Kovalchuk L.Ye. and co-authors [28]. The preparations were examined by light microscopy using the optical-elec- tronic complex "Metascan-2" of the Genetic Laboratory of the Department of Medical Biology and Medical Genetics, Ivano-Frankivsk National Medical University, Ukraine.

A comprehensive analysis of four indices of karyogram (nucleolar (IN), chromatization, heteropyknotic X-chromosome and pathologically altered nuclei (PAN) was performed according to the method of Kovalchuk L.Ye. and co-authors $[28,29]$ in 100 interphase nuclei of peripheral blood leukocytes.

The index of chromatization (IC) was calculated according to the ratio of nuclei with the superiority of uncondensed chromatin (euchromatin) to nuclei containing large sections of heterochromatin. The percentage of the above-mentioned cells was determined individually.

Nucleolar index (IN), which indicates the total metabolism of cells, was determined by the ratio of nuclei that had nucleoli to the total number of nuclei. Cells with a heteropyknotic X-chromosome, i.e., those that contained gender chromatin, were registered. At the same time, the incidence of pathologically altered nuclei (PAN) and micronuclei index (MNI), were recorded.

To objectify the obtained data, there were examined 20 patients with $\mathrm{CHC}$ without concomitant DM-2, who made up the comparison group, and 20 healthy individuals of the same age ( 10 men and 10 women), who were included into the control group.

Licensed statistical analysis packages of Microsoft Excel and Statistica 7.0 were used for statistical processing.

\section{RESULTS}

In practically healthy persons, the processes of chromatin (IC) decondensation were predominant in women $(1.48 \pm 0.16 \%)$ versus $(1.10 \pm 0.07 \%)$ in men $(\mathrm{p}<0.05)$ (Fig. 1$)$.

Comparative analysis of FSG of NGPB indices in patients of both study groups revealed changes in all components of NGPB metabolism. In the early stages of cell apoptosis, the destruction of nuclear proteins is accompanied by chromatin condensation.

In the study of the PAN index, nuclei with various pathological inclusions were noted in both study groups, among which vacuolated nuclei, heteropyknotic cells, and nuclei with deep karyolemma invaginations were predominant (Fig. 2).

Reduction of IC in both study groups compared with those in healthy people was determined $(\mathrm{p}<0.01, \mathrm{p}<0.001)$ (Table I).

Table I. Indices of chromatization, pathologically altered nuclei and nucleolar index of peripheral blood neutrophilic granulocytes in the studied persons, $\mathrm{M} \pm \mathrm{m}$

The magnitude of IC in women of the main group was 1.2 -fold less than in women without concomitant DM-2 $(\mathrm{p}<0.05)$. Gender dimorphism in relation to IC was not observed in all the studied patients $(\mathrm{p}>0.01)$. The revealed changes can be explained by a significant decrease of the compensatory abilities of cell metabolism, an increase of cell apoptosis in patients with CHC, especially in the presence of comorbid conditions.

A decrease of IN at $51.70 \%$ in patients without concomitant DM-2 $(\mathrm{p}<0.001)$ and at $58.50 \%$ in patients with 

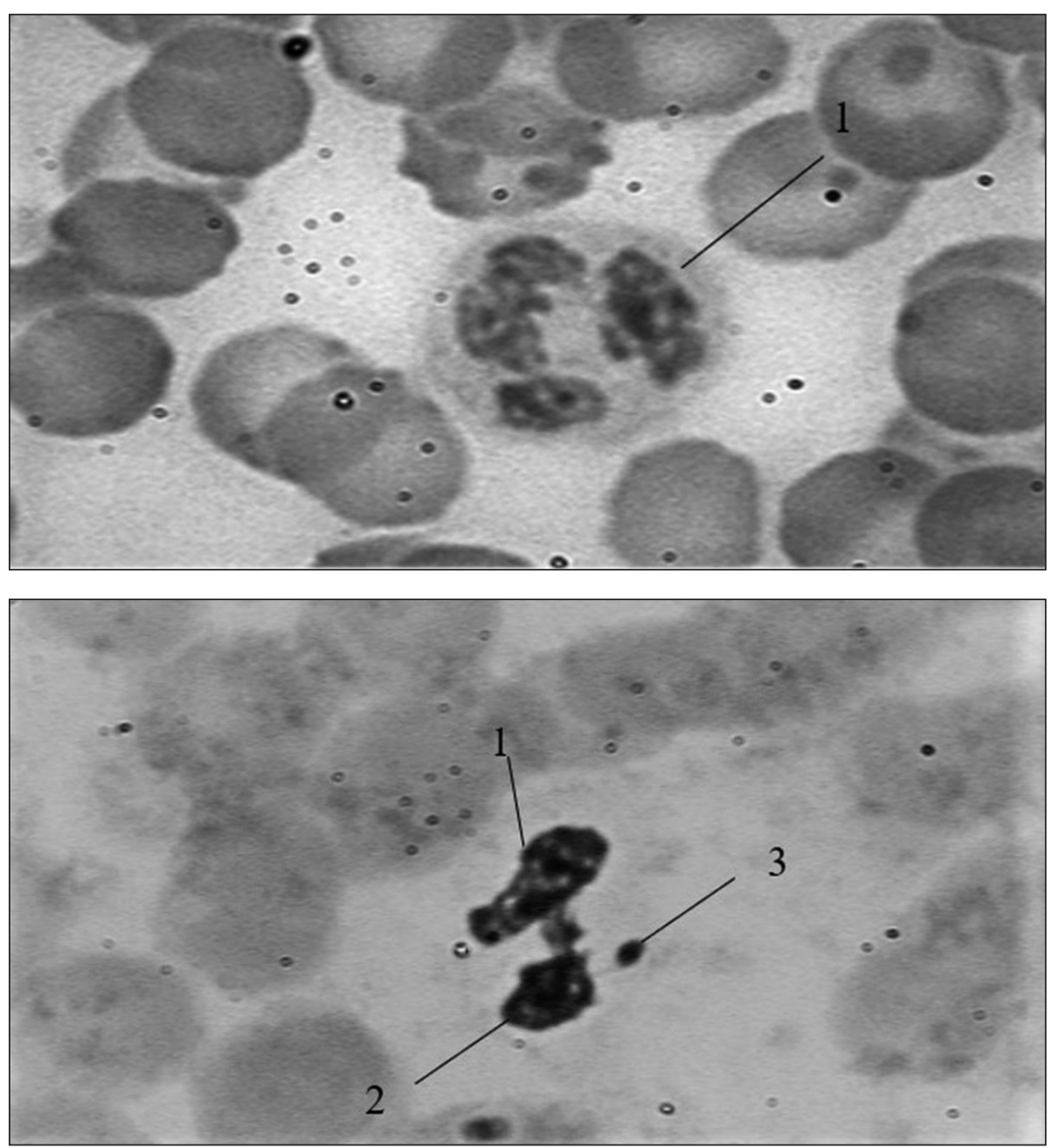

Fig. 1. 1 - the nucleus of neutrophilic peripheral blood granulocyte with euchromatin preference in a healthy person. Feulgen staining in Kovalchuk modification. Magnification: field lens 40; ocular lens 15.

Fig. 2. Nuclei of neutrophilic granulocytes of peripheral blood in patients with chronic hepatitis C with concomitant type 2 diabetes mellitus. Feulgen staining in Kovalchuk modification. Magnification: field lens 40; ocular lens 15. (1 - vacuolated nucleus; 2 - heterochromatin-dominated nucleus; 3 - micronucleus formation).
CHC with concomitant DM-2 $(\mathrm{p}<0.001)$ may indicate the impaired ribosomal RNA gene amplification and the decreased readiness of ribosomes to the synthesis of the polypeptide chain due to the influence of HCV-infection. However, no gender dimorphism was determined and no significant difference between the two study groups $(\mathrm{p}>0.05)$ (Table I).

The number of PAN in $\mathrm{CHC}$ without concomitant pathology increased 2.4-fold $(\mathrm{p}<0.001)$, and in patients with CHC with concomitant DM-2 - 2.8-fold ( $\mathrm{p}<0.001)$ compared with the control. Patients with $\mathrm{CHC}$ with concomitant diabetes mellitus type 2 the number of PAN was significantly higher than in patients with $\mathrm{CHC}$ without concomitant pathology $(11.08 \pm 0.31 \%$ vs. $9.60 \pm 0.39 \%$; $\mathrm{p}<0.01)$. No gender dimorphism was found regarding this index $(\mathrm{p}>0.05)$ (Table I).

The expressed changes of cytogenetic parameters in patients with $\mathrm{CHC}$ may be due to the direct cytopathic action of HCV and its ability to inhibit the mechanisms of DNA replication and transcription due to the disorder of the endonuclease activity.

As the index of the heteropyknotic X-chromosome needs to be considered according to gender, we've determined its quantitative characteristics in men and women patients with $\mathrm{CHC}$ without concomitant pathology and with con- comitant DM-2. There was a decrease of the level of IC in women with $\mathrm{CHC}$ both with concomitant DM-2 and without concomitant pathology compared to the control group and its appearance in the nuclei of some men of both study groups (Table II).

We've also examined the presence of IN, that indicates more profound violations of the hereditary apparatus of the NGPB (Table III).

We must note, that micronuclei formation is caused by changes of chromosome structure during the process of mitosis. Analyzing the MNI index, we did not find a significant difference according to this index between the main group and the comparison group $(0.83 \pm 0.10 \%)$ against $(1.05 \pm 0.20 \%)$, respectively $(\mathrm{p}>0.05)$, and gender in these study groups ( $\mathrm{p}>0.05)$ (Table III).

There was also no significant difference $(p>0.05)$ between the number of $\mathrm{MNI}$ of healthy persons and patients with $\mathrm{CHC}$ with concomitant DM-2 and with $\mathrm{CHC}$ without concomitant pathology $(\mathrm{p}>0.05)$. Gender dimorphism was also absent ( $p>0.01$ ) when comparing the MNI index in these groups of patients and in practically healthy persons (Table III).

Thus, in the HCV-infection combined with DM-2 the transcriptional-transcriptional abnormalities deepen compared with those in patients with $\mathrm{CHC}$ without concomitant pathology. 
Table I. Indices of chromatization, pathologically altered nuclei and nucleolar index of peripheral blood neutrophilic granulocytes in the studied persons, $\mathrm{M} \pm \mathrm{m}$

\begin{tabular}{|c|c|c|c|c|}
\hline Index & & $\begin{array}{c}\text { CHC and } \\
\text { concomitant DM/ } \\
\text { men - 80; } \\
\text { women - } 80\end{array}$ & $\begin{array}{c}\text { CHC without } \\
\text { concomitant DM/ } \\
\text { men - 10; } \\
\text { women - 10 }\end{array}$ & $\begin{array}{c}\text { Control group/ } \\
\text { men - 10; } \\
\text { women - } 10\end{array}$ \\
\hline \multirow{3}{*}{ Chromatization \% } & both sexes & $0.78 \pm 0.02^{\#}$ & $0.85 \pm 0.03^{*}$ & $1.28 \pm 0.09$ \\
\hline & men & $0.80 \pm 0.02^{\#}$ & $0.82 \pm 0.05^{* *}$ & $1.10 \pm 0.07$ \\
\hline & women & $0.76 \pm 0.02^{\# @ ~}$ & $0.88 \pm 0.04^{*}$ & $1.48 \pm 0.16$ \\
\hline \multirow{3}{*}{ Nucleolar, \% } & both sexes & $3.05 \pm 0.14^{\# \wedge}$ & $3.55 \pm 0.28^{*}$ & $7.35 \pm 0.80$ \\
\hline & men & $3.05 \pm 0.23^{\#}$ & $3.70 \pm 0.45^{*}$ & $8.30 \pm 1.13$ \\
\hline & women & $2.98 \pm 0.19^{\# \#}$ & $3.40 \pm 0.34^{* * *}$ & $6.40 \pm 1.10$ \\
\hline \multirow{3}{*}{ Pathologically changed nuclei, \% } & both sexes & $11.08 \pm 0.31^{\# @ ~}$ & $9.60 \pm 0.39^{*}$ & $3.89 \pm 0.66$ \\
\hline & men & $10.75 \pm 0.43^{\# @ ~}$ & $9.50 \pm 0.45^{*}$ & $4.00 \pm 0.98$ \\
\hline & women & $11.43 \pm 0.45^{\# @ ~}$ & $9.70 \pm 0.65^{*}$ & $3.40 \pm 0.91$ \\
\hline
\end{tabular}

Notes:

1. * - significance of difference between comparison group and control group $(\mathrm{p}<0.05)$;

2. \# - significance of difference between indices of the main and control groups $(p<0.05)$;

3. @ - significance of difference between the indices of the main group and the comparison group $(p<0.05)$;

4. $\wedge$ - significance of difference compared with women of main group, comparison group, control group $(p<0.05)$.

Table II. Changes in gender chromatin index in the examined patients, $\mathrm{M} \pm \mathrm{m}$

\begin{tabular}{ccccc} 
Index & & $\begin{array}{c}\text { CHC and } \\
\text { concomitant DM/ } \\
\text { men - 80; } \\
\text { women - 80 }\end{array}$ & $\begin{array}{c}\text { CHC without } \\
\text { concomitant DM/ } \\
\text { men - 10; } \\
\text { women - 10 }\end{array}$ & $\begin{array}{c}\text { Control group/ } \\
\text { men - 10; } \\
\text { women - 10 }\end{array}$ \\
\hline sex chromatin \% & men & $6.15 \pm 0.43 \wedge$ & $5.95 \pm 0.91^{\wedge}$ & $5.20 \pm 0.96^{\wedge}$ \\
\cline { 2 - 5 }
\end{tabular}

Notes:

$1 .^{*}$ - significance of difference between comparison group and control group $(p<0.05)$;

2 . \# - significance of difference between main group and control group $(p<0.05)$;

3. $\wedge$ - significance of difference compared with women of main group, comparison group, control group ( $<<0.05)$.

Table III. The index of micronuclei index of the examined patients, $M \pm m$

\begin{tabular}{lcccc}
\hline Index & & $\begin{array}{c}\text { CHC and } \\
\text { concomitant DM/ } \\
\text { men - 80; } \\
\text { women - 80 }\end{array}$ & $\begin{array}{c}\text { CHC without } \\
\text { concomitant DM/ } \\
\text { men - 10; } \\
\text { women - 10 }\end{array}$ & $\begin{array}{c}\text { Control group/ } \\
\text { men - 10; } \\
\text { women - 10 }\end{array}$ \\
\hline \multirow{2}{*}{ micronucleus, $\%$} & both sexes & $0.83 \pm 0.09$ & $1.05 \pm 0.20$ & $0.80 \pm 0.05$ \\
\cline { 2 - 5 } & men & $0.90 \pm 0.15$ & $1.00 \pm 0.26$ & $0.88 \pm 0.08$ \\
\cline { 2 - 5 } & women & $0.78 \pm 0.13$ & $1.10 \pm 0.31$ & $0.72 \pm 0.02$ \\
\hline
\end{tabular}

\section{DISCUSSION}

In the process of studying the functional state of the hepatocytes genome in patients with chronic hepatitis according to hepatocytes interphase nucleus karyogram measurement, impaired components of the transcription-translation apparatus were discovered, including IC reduction comparing to the ones in healthy people $(\mathrm{p}<0,001)$ and patients without concomitant diabetes type $2(\mathrm{p}<0,001)$ that might mean a dramatic decline in cell metabolism compensation abilities in patients with chronic hepatitis having diabetes type 2 . Besides, because of $\mathrm{HCV}$-infection influence gene amplification of the ribosomal RNA and diminished ribosomes readiness to synthesize polypeptide chain were occurring and declaring as nucleolar index reduction of $51,7 \%$ in patients with chronic hepatitis without concomitant pathology $(\mathrm{p}<0,001)$ and of $58,5 \%$ in patients with chronic hepatitis having diabetes type 2 $(\mathrm{p}<0,001)$ comparing to healthy individuals. The increasing of pathologically altered nuclei levels in such patients clearly demonstrated the impaired structural state of cells and as a result the reduction of their ability for reparation In addition to the evaluation of the impaired NGPB genetic 
set, the micronuclei index was determined as far as its formation is caused by changes in chromosome structure in the process of mitosis. We didn't detect the significant difference between MRI in patients with chronic hepatitis having diabetes type 2 and patients with chronic hepatitis without concomitant pathology ( $p>0,1)$ and difference between genders. However, in the study process, the tendency to cytogenetic status components changes in all examined patients according to MNI frequency has been determined.

\section{CONCLUSIONS}

In the course of the study we have proved:

1. Significant disorders of the functional state of the NGPB genome in patients with $\mathrm{CHC}$ with concomitant type 2 diabetes mellitus compared with patients with $\mathrm{CHC}$ without concomitant diabetes.

2. Decrease of the level of IC $(0.78 \pm 0.02)$ in patients with $\mathrm{CHC}$ with concomitant type 2 diabetes mellitus was more pronounced in men of all study groups. Significant reduction of MNI in all patients with $\mathrm{CHC}$ with concomitant DM-2 and without concomitant pathology $(3.05 \pm 0.14 \%)(\mathrm{p}<0.001)$ compared with the control, which may be a marker of the depth of disorders of the second stage of implementation of hereditary information $(\mathrm{p}>0.1)$ was determined.

3. The tendency to change the components of the cytogenetic status of all examined patients by frequency of micronuclei was determined.

\section{REFERENCES}

1. Hanafiah K.M., Groeger J., Flaxman A.D. et al. Global epidemiology of hepatitis C virus infection: New estimates of age-specific antibody to HCV seroprevalence. Hepatology. 2013; 57:1333-1342.

2. Popping S., El-Sayed M., Feld J., Hatzakis A., et al. Report from the International Viral Hepatitis Elimination Meeting (IVHEM), 17-18 November 2017, Amsterdam, the Netherlands: gaps and challenges in the WHO 2030 hepatitis Celimination framework. JVirus Erad. 2018; 4 (3): 193-195.

3. Giada S., Gkouvatsos K., Pantopoulos K. Chronic hepatitis C and liver fibrosis. World J Gastroenterol. 2014; 20(32):11033-11053.

4. Saeedi P., Petersohn I., Salpea P., Malanda B. et al. Global and Regional Diabetes Prevalence Estimates for 2019 and Projections for 2030 and 204 5: Results From the International Diabetes Federation Diabetes Atlas, 9 th Edition, Diabetes Res Clin Pract. 2019; (9):10 D0l: 10.1016/j. diabres.2019.107843.

5. Zheng Y., Ley S.H., Hu F.B. Global aetiology and epidemiology of type 2 diabetes mellitus and its complications. Nat Rev Endocrinol. 2018;14(2):88-98.

6. Aytug S., Reich D., Sapiro L.E. et al. Impaired IRS-1/PI3-kinase signaling in patients with $\mathrm{HCV}$ : a mechanism for increased prevalence of type 2 diabetes. Hepatology. 2003; 38(6):1384-92.

7. LiY., Wang X., Yu G. et. al. The association of hepatitis c virus infection status with serum glucose levels. BMC Gastroenterol. 2019;19(1):86.

8. Guo X., Jin M., Yang M. et. al. Type 2 diabetes mellitus and the risk of hepatitis C virus infection: A systematic review. Sci. Rep. 2013; 3:2981.

9. Desbois A.C., Cacoub P. Diabetes mellitus, insulin resistance and hepatitis C virus infection: a contemporary review. World J Gastroenterol. 2017; 23(9):1697-711.
10. Drazilova S., Gazda J., Janicko M. et. al. Chronic Hepatitis C Association with Diabetes Mellitus and Cardiovascular Risk in the Era of DAA Therapy. Gastroenterol Hepatol. 2018; 2018:615-861.

11. Antonelli A., Ferrari S.M., Giuggioli D. et al. Hepatitis C virus infection and type 1 and type 2 diabetes mellitus. World J. Diabetes. 2014;5:586.

12. Antonelli A., FerriC., FerrariS.M. et al. Endocrine manifestations of hepatitis C virus infection. Nat Clin Pract Endocrinol Metab. 2009; 5:26-34.

13. Janisch R., Birg A. Epigenetic regulation of geno expression. Nature Genetics. 2003; 2(33): 245-254.

14. Grozdev V.A., Usakin L.A., Kochan R.L. Geterokhromatin i ego funktsionalnyie kharakteristiki [Heterochromatin and its functional characteristics]. Med. Genetika. 2003; 7(2):290-296.

15. Newburger P.E., Subrahmanearn Y.V., Weissman S.M. Global analysis if neutrophil gene expression. Cur. Opin. Haematol. 2000;7(1):16-20.

16. Makashova V.V., Kuznetsov S.D., Tutelyan A.V. Kliniko-geneticheskie vzaimosviazi u bolnykh khronicheskim gepatitom C [Clinical-genetic relationships in patients with chronic hepatitis C]. Epidemiologiia i infektsionnyie bolezni.2016; 5:55-59.

17. Janisch R., Birg A. Epigenetic regulation of geno expression. Nature Genetics. 2003; 2(33): 245-254.

18. Neiko Ye.M., Kovalchuk L.Ye., Cherniuk N.V. Epihenetychni mekhanizmy rehuliatsiyi aktyvnosti heniv i multyfaktorni khvoroby [Epigenetic mechanisms of regulation the activity of genes and multifactorial diseases]. Galician Medical Journal. 2007; 1(14):11-14.

19. Feinberg A. The Key Role of Epigenetics in Human Disease. N Engl J Med. 2018; 379(4):400-401.

20. Virstiuk N.H., Kovalchuk L.Ye., Cherkashyna O.Ye. Dynamika tsytohenetychnykh pokaznykiv neytrofiliv peryferychnoi krovi u khvorykh iz khronichnoyu sertsevoyu nedostatnistiu [Dynamics of cytogenetic indices of peripheral blood neutrophils in patients with chronic heart failure]. Laboratorna diahnostyka. 2010; 3:25-27.

21. Paliichuk Y.V., Kovalchuk L.Ye., Yastrebova 0.Ya. Tsytohenetychni pokaznyky funktsionalnoho stanu henomu neytrofilnykh hranulotsytiv peryferiinoi krovi u khvorykh na protezni stomatyty [Cytogenetic indices of the functional state of the genome of neutrophils peripheral blood in patients with prosthetic stomatitis]. Visnyk stomatolohiyi. 2010; 3:59-64.

22. Kaminsky V.Ya. Otsinka funktsionalnoho stanu khromatynu neitrofilnykh hranulotsytiv u patsiyientiv iz khronichnoiu khvoroboyu nyrok, hlomerulonefrytom [Evaluation of the functional state of neutrophils' granulocytes chromatin in patients with chronic kidney disease, glomerulonephritis]. Ukrainsky medychny almanakh. 2012; 3(15):83-85.

23. Virstiuk N.H., Kovalchuk L.Ye. Diahnostychne znachennia tsytohenetychnykh pokaznykiv u khvorykh na khronichni hepatyty [Diagnostic value of cytogenetic indices in patients with chronic hepatitis]. Galician Medical Journal. 2001; 4(8):23-25.

24. Barilyak I.R., Frolov V.M., Pinskiy L.L. et al. Tsitogeneticheskie narusheniya u bolnykh khronicheskimi gepatitami B i C [Cytogenetic disorders in patients with chronic hepatitis $B$ and $C$. Tsitologiya $i$ genetika. 2000; 4(3):3-5.

25. Pinskiy L.L. Vzaimosviaz tsitogeneticheskikh i immunologicheskikh pokazateley u bolnyikh khronicheskim gepatitom B [Interrelation of cytogenetic and immunological indices in patients with chronic hepatitis B]. Kyiv; 2001, 50-54.

26. Moroz L.V. Imunohenetychnyi profil u khvorykh na khronichnyi hepatyt C [Immunogenetic profile in patients with chronic hepatitis C]. Hepatolohiya. 2011; 2:28-33. 
27. Sakakura C., Hagivara A., Tanaguchi H. et al. Chromosomal aberrations in human hepatocellular carcinomas associated with hepatitis C virus infection detected by comparative genomic hybridization. Brit. J. Cancer.1999; 12(80):2034-2039.

28. Kovalchuk L.Ye., Kovalchuk N.V., llyk V.V. Ivano-Frankivskyi derzhavnyi medychnyi universytet. Vyiavlennia DNK v tsytolohichnykh preparatakh [Ivano-Frankivsk State Medical University. Detection of DNA in cytological preparations. Ukraine: Innovation Offer]. Ukraine: ratsionalizatorska propozytsiia [innovative proposal] №30/2319. 1997; 3 p.

29. Kovalchuk L.Ye. Tsytokhimichni aspekty funktsionalnoho stanu henomu ta rozvytku multyfaktornykh khvorob [Cytochemical aspects of the functional state of the genome and the development of multifactorial diseases]. Galician Medical Journal. 2002; 4:33-36.

The scientific study was performed within the framework of the scientific-research work of the Department of Infectious Diseases and Epidemiology of the Ivano-Frankivsk National Medical University (Ukraine) "The course of infectious diseases against the background of concomitant pathology, combined chronic infections and invasions, treatment correction", state registration number 0119 U100571.

\section{ORCID and contributionship:}

Oleksandra Ya. Pryshliak: 0000-0002-3256-5108 ${ }^{F}$

Larysa Ye. Kovalchuk: 0000-0003-2878-3441 ${ }^{D}$

Oleksandra V. Marynchak: 0000-0002-6052-4485 ${ }^{B}$

Oleksandr P. Boichuk: 0000-0003-0646-6533 ${ }^{\mathrm{A}}$

Ihor H. Hryzhak: 0000-0002-5131-0223 ${ }^{E}$

Oksana Ye. Kondryn: 0000-0002-0255-810X ${ }^{C}$

Valentyna F. Piuryk: 0000-0001-8983-4359 C

\section{Conflict of interest:}

The Authors declare no conflict of interest.

\section{CORRESPONDING AUTHOR}

Oleksandr P. Boichuk

Ivano-Frankivsk National Medical University

44-A Molodizhna st., 76009 Ivano-Frankivsk, Ukraine

tel: +380506749109

e-mail: opboy@ukr.net

Received: 28.09.2019

Accepted: 05.06 .2020
A - Work concept and design, B - Data collection and analysis, C - Responsibility for statistical analysis, D-Writing the article, $\mathbf{E}$-Critical review, $\mathbf{F}$ - Final approval of the article 